\title{
Reading Culture in An African University: Problems And Prospects
}

\section{By}

\author{
Oyewumi, Olatundun O. and Ebijuwa, Adefunke S.
}

\begin{abstract}
This paper examined if undergraduates of African universities have reading culture or not. To elicit the necessary information, a questionnaire was randomly distributed to 200 students from $100-500$ level and a response rate of $100 \%$ was achieved. Using simple percentage response rate to analyze the data, the results showed that only $21 \%$ of the respondents have poor reading culture, while majority of them (59.5\%) read for interest only. The paper therefore recommended ways by which librarians; lecturers and parents can encourage undergraduates to read, to improve and to inculcate good reading culture.
\end{abstract}

\section{Introduction:}

The acquisition of knowledge for the development of man, society and nature does not arise from a vacuum. This can be done partly through formal training which involves mostly a; "determined, result oriented information processing efforts" by the individual, through reading (Ugwoke, 2004). Thus, besides being a ready source for acquisition of information, reading is an effort aimed at sifting received opinions in order to cope with the challenges of the everyday experiences. The word sifting is used because sometimes, received opinion may not be adequate for ones contemporary needs and interests. Since man's existence depends on ability to cope with the challenges of survival, it is important to develop the critical attitude to meeting them. This obviously makes the proper cultivation of reading culture impetrative. This is so not only because Holte (1998) avers that reading adds quality to human existence, empowers and emancipates man and society, but rather that reading creates the atmosphere that makes human freedom inevitable. Certainly, reading culture in a university like Ladoke Akintola University of Technology, Ogbomoso will obviously have some problems.

Before going into the discussion of problems associated with reading in a Nigerian university, in this case, Ladoke Akintola University of Technology, Ogbomoso it is necessary to look, if only briefly, at the purposes of reading. This is pertinent because it will enable us have a proper perspective of the nature of the problems readers go through. Onwubiko (1985) has identified four main purposes why people engage in reading activity as;

1. reading for pleasure;

2. information;

3. knowledge;

4. any combination of the above.
All of these are important for the development of man and society. Yet, the last two seems to us the most significant because it puts a man who engages is reading for these purposes over and above those who read for pleasure or for mere information. It is true to say that the man with information is better than the one who lacks information. But mere acquisition of information without in-depth appreciation and utilization of it for personal development, society and nature can simply be described as the spider and its meaningless beautiful web. Put differently, whichever way it is looked at, reading culture in universities is far from being appreciated. Hitherto, reading used to be a combination of Onwubiko's items three and four above. As of now, the researchers observed that students merely read to pass examinations and not necessarily for the acquisition of knowledge for useful purposes. For them, reading is a means to an end. However, for an individual to find his way in the complex and fast changing world in which he lives, reading should transcend simply passing examinations (Ogunrombi and Adio, 1995), 'beating' the guy next door or winning accolades from their mentor.

\section{Reading Culture}

The term 'culture' can be said to be a result of people's interaction with their environment. It embodies the habits and attitudes shared by a society. To develop a culture of reading in a society, it requires knowledge to utilise time, existing information materials and resources. It is of importance to mention that the quality of life of an individual depends on his use of human and nonhuman resources at his disposal. According to Olubor and Osunde (2007) time is one of the most important human resources available to individuals and families irrespective of their socio-cultural, economic and intellectual backgrounds. Thus, students should consider resource allocations and decisions affecting 
the limited amount of time available to them to carry out their daily activities which include personal study, assignments and leisure effectively. Nye (2000) is rather of the opinion that culture are done, practiced and manifested while Magara and Batambuze (2005) in their study 'towards a reading culture' are of the view that reading culture involves a daily activity as essential as a habit and developing a reading culture according to Makenzi (2004) is an instrument for acquiring life long learning. This requires the ability to recognise access, evaluate and utilise information in the available literature or information materials.

Reading culture among university undergraduates is changing and this is a worrying development. The British Broadcasting Corporation News (2005) reported that access to books in Africa is often difficult and expensive and only a few countries like Kenya, South Africa and Nigeria have a significant book trade. Thus, if a large number of people rarely read, either because they lack the skill, not motivated, high cost of books or simply because it is not yet examination period, it will surely pose serious problems in the future because reading adds quality to life and provides access to culture and cultural heritage (Holte, 1998). It helps to uncover the understanding of somebody else's wisdom- wisdom that may have taken a lifetime to regurgitate in the pages (Rijal, 2005). Moreover, to ensure that reading thrives among university undergraduates and in Africa bearing in mind that Africa is a predominantly oral society, Makenzi (2004) posits that concerted efforts would be required to improve the social and reading infrastructure, promote reading across the school curriculum and develop reading extension services. In addition, lecturers should make use of modern teaching technology and give out continuous assignments that involve students making use of the library to encourage undergraduate reading.

\section{Problems of reading culture}

What then is militating against the development of reading culture? First, is the general dislocation of values in the African landscape by colonialism and the platform of poverty such dislocation generated. Under colonialism, social services and amenities were far from the people they were meant to "serve". Even in most instances where such services were available they were meant to facilitate exploitation, they were not directly producing surplus for export to metropolis. That is to say, none of the wealth of exploited Africans could be deployed for the assistance of their brothers outside the money economy (Rodney,1972). To perpetuate this injustice and exploitation, the colonialist created a kind of divide and rule system which made people to distance themselves from one another thereby creating suspicion amongst "natives" which later degenerated into ethnic clashes in different locations.

The above clearly leads to one thing, that is, under development. When a society is exploited as we find in many colonized states, it is not only people that are disposed that are found, we also find people in poverty. We cannot be talking about reading culture when those who should be reading are either fighting wars as we find in Liberia, Sudan, Sierra-Leone, Rwanda, Burundi, Cote-d'voire or looking for how to put food in their stomach.

There is also what has been identified as a cultural problem. Commeyras (2001) for example sees Africa as predominantly an oral culture where people love to talk and interact with one another rather than read. For her, since Africa is purely a communalistic society, it is difficult to introduce a purely western systematic reading style that is individualistic in character, but the question is; is Commeyras (2001) referring to traditional African societies or contemporary African societies? If the reference is to the former, then there is not much to argue about. But if is to the latter, then she may not be totally correct. For, African societies have undergone fundamental transformation in the direction of individualism so much so that those factors that influenced the systemic reading culture in western societies are gradually traceable in African societies. So, it cannot be true as Commeyras (2001) avers that: "among Africans - busying oneself with a book while others are conversing would inexorably lead to a loss of certain valuable knowledge and experience". Here, Commeyras (2001) seems to argue to the claim that African knowledge acquisition revolves around "folklore, anecdotes, shared experiences, proverbs and even gossips. This seems to us ridiculous because the critical force which the challenge of received opinions bring to bear in human communication whether oral or textual is ruled out of court from the above showing.

Related to the above is what Kotei (1978) associated with African society negatively affecting the development of inquisitive attitudes. We agree with Kotei (1978) that the authoritarian character of African societies inhibits inquisitive attitudes. It is also important to note that authoritarian tendencies featured prominently in communalistic traditional African societies as against what is presently experienced in contemporary African moving on the 
part of individualism. Here, it is expected of people to purchase reading materials and after doing so, question the ideas therein. Authoritarianism has nothing to do with the availability of books. But even when books are available, they are rarely read because the motivation to read is impaired by what we call the "full-belle" thesis hunger. Thus, unless the poverty level is reduced in our society, a situation that is directly related to the crisis of development in African, people will continually read, not for the sake of knowledge production for social and economic development, but for examinations only.

\section{Statement of the problem}

Access to books in Africa according to the British Broadcasting Corporation News (2005) is often difficult and expensive, and only a few countries like Kenya, South Africa and Nigeria have a significant book trade. Often, the government is the biggest purchaser of books, particularly textbooks for schools, but children and youths do not respond well to textbooks especially in the world of digital age and they may not be good at reading them. Oyimnatumba (2008) also acknowledges that there is a dearth of reading culture. She is of the opinion that the objective of loan among university students is to buy musical compact discs or and digital video discs while their line of discussion is when and where is the next party. This therefore prompted an investigation into the reading culture of undergraduates using Ladoke Akintola University of Technology, Ogbomoso as a case study, with the belief that the results and findings would assist other undergraduates in forming a good reading culture.

\section{Objectives}

The study was guided by four objectives; namely:

1. to examine factors which influence reading culture among undergraduates

2. investigate if there are adequate reading materials in the library or otherwise

3. find out how to promote better reading habits

4. examine how undergraduates can be encouraged to love reading in a digital age

\section{Methodology}

The data for this study were collected by administering questionnaire to 200 students from all levels $(100-500)$ of the university. The selection was done from statistics of readers that use the library per week between the hours of 10.00a.m and 12.00 noon from Monday to Friday before examination period. The total number of users between these periods for five days totalled 1004. An average of 200 users cutting across 100 - 500 levels was therefore captured. Variables such as age, gender, use of leisure hours, ownership of books, kind of books read, access to books were among questions answered by the respondents. The questionnaire was administered in four different reading rooms of the university library with the help of six research assistants and collected on the spot. All the copies of the questionnaires were returned and analyzed.

\section{Results and Findings}

From Table 1 bellow the distribution of registered and unregistered library users. 99\% of the students were duly registered with the library while $0.5 \%$ was not. Also $0.5 \%$ of the students were undecided. The percentage of the registered library users is an indication that students know the importance of library use in their academic work.

Table 2 revealed the frequency of library use. 33\% use the library daily, while $5 \%$ use it twice a week. Less than $28 \%$ use it thrice a week as they dim fit. $4 \%$ use it fortnightly while less than $31 \%$ were undecided about their use of library.

Table 3 indicates what students read. A large percentage of $67 \%$ indicated that they use the library to read class notes, $20 \%$ read newspapers, less than $2 \%$ indicated using the library to read textbooks available and related to their discipline. The total number of respondents was more than 200 because students chose more than one option. The results shows that students rely more on notes taken in class more than textbooks probably because they cannot afford to buy recommended textbooks due to the economic situation in the country and because the textbooks available in the library are not enough to go round all the users. 
Table 1: Distribution of registered and unregistered library users

\begin{tabular}{|l|c|l|}
\hline & No of Respondents & \% \\
\hline Registered users & 198 & 99 \\
\hline Unregistered users & 1 & 0.5 \\
\hline Nil & 1 & 0.5 \\
\hline
\end{tabular}

Table 2: Frequency of respondent's library use

\begin{tabular}{|l|c|l|}
\hline \multicolumn{1}{|c|}{ Frequency } & No of Respondents & \multicolumn{1}{c|}{$\%$} \\
\hline Everyday & 66 & 33 \\
\hline Twice a week & 10 & 5 \\
\hline Thrice a week & 55 & 27.5 \\
\hline Fortnightly & 8 & 4 \\
\hline Others & 61 & 30.5 \\
\hline
\end{tabular}

Table 3: Distribution of what students read

\begin{tabular}{|l|c|c|}
\hline \multicolumn{1}{|c|}{ Items } & No of respondents & \% \\
\hline Class notes & 134 & 67 \\
\hline Textbooks & 130 & 65 \\
\hline Newspapers & 40 & 20 \\
\hline Others & 16 & 8 \\
\hline Novels & 6 & 3 \\
\hline Junk magazines & 3 & 1.5 \\
\hline
\end{tabular}

Table 4: Distribution of what motivates students to read

\begin{tabular}{|l|c|c|}
\hline \multicolumn{1}{|c|}{ Items } & No of respondents & \% \\
\hline Examination & 134 & 67 \\
\hline Interest & 119 & 59.5 \\
\hline Reading culture & 42 & 21 \\
\hline Pleasure & 30 & 15 \\
\hline Others & 23 & 11.5 \\
\hline Boredom & 5 & 2.5 \\
\hline
\end{tabular}

Table 5: Distribution of why students do not read

\begin{tabular}{|l|c|c|}
\hline \multicolumn{1}{|c|}{ Items } & No of respondents & \% \\
\hline No time & 43 & 21.5 \\
\hline Outdated textbooks & 39 & 19.5 \\
\hline No seating space & 26 & 13.5 \\
\hline Unorganized materials & 16 & 8 \\
\hline High cost of books & 10 & 2.5 \\
\hline Availability of computers/internet & 5 & 1.5 \\
\hline Handbooks & 3 & 37 \\
\hline Others & 74 & \\
\hline
\end{tabular}


Table 6: Distribution of how frequent students read

\begin{tabular}{|c|c|c|c|c|}
\hline Agree & Disagree & $\begin{array}{c}\text { Strongly } \\
\text { Agree }\end{array}$ & $\begin{array}{c}\text { Strongly } \\
\text { Disagree }\end{array}$ & Undecided \\
\hline $16 \%$ & $14 \%$ & $15 \%$ & $15 \%$ & $40 \%$ \\
\hline
\end{tabular}

Table 4 showed what motivates students to read. It was observed from the result that students are motivated to read by different reasons. $15 \%$ are motivated to read for pleasure. 59.9\% for interest, $21 \%$ read because they have a reading culture, while the greater percentage of $67 \%$ read because they want to pass examinations. Less than $3 \%$ read because they are bored, while less than 125 are motivated by other reasons. The results indicate that students do not have a reading culture.

Table 5 showed that students are lazy and do not want to read to acquire more knowledge and this is an indication of their lack of reading culture because from the data collected, the results showed that $21.5 \%$ of them indicated that they do not have time to read which is their primary assignment. While 37\% are undecided about why they read, $5 \%$ indicated that they do not read because of the availability of computers/internet.

The results in table 6 above indicates that majority of the students do not have a reading culture. $40 \%$ are undecided about whether they have a reading culture or not. $16 \%$ agree that they have a reading culture while $15 \%$ strongly agree to that fact as well. $14 \%$ disagree to the fact that they have a reading culture while $15 \%$ strongly disagree that they have a reading culture. The respondents were asked what they think the library can do to help promote better reading culture and they gave various suggestions. The respondents feel the library management should know what the readers require by giving them proper library orientation when admitted into the institution. This should be followed up by organizing reading competition and seminars on the advantages of reading for students while also providing audiovisual materials to assist learning.

In addition, respondents feel that the library management should put their catalogue card box in place, have a standby generator, acquire more relevant textbooks in multiple copies and journals both local and international spread across all departments, make sure that there is proper exhibition done for new arrivals/collections, while outdated, mutilated or torn textbooks should be weeded and repaired accordingly.

\section{Conclusion}

This study clearly indicates that the library has a lot of work to do to encourage reading culture among undergraduates. Students require a guide called reading with a purpose. They require availability of organized books, magazines, newspapers and nonbook materials. It is equally expected that youths should have basic education as foundation on which their potentials could be identified and developed. Ingham (1993) is of the opinion that literacy is essential if peoples are to be able to communicate, appreciate their culture, obtain and keep jobs. Therefore, lecturers, parents, librarians and all concerned in shaping the emotional, cultural, educational growth and development of children must inculcate and nurture in them a good reading culture which in turn will arouse their interest in reading and mould their character. Thus, student should read not only for pleasure but to learn and acquire more knowledge in their studies and for their personal development.

\section{Recommendation}

The education of a child according to Jam (1996) is so important to the existence of any nation because the child of today grows into tomorrow's adult and thus, the community and survival of the nation is ensured. To encourage students to read calls for the lecturer, librarian and parents to show interest in the attitude of students to books and not only to their needs because undergraduates cannot develop an effective reading culture without the home, school, library and a conducive environment which all play major roles.

Besides, Michael Gonzales, Deputy Director of the American Resource Centre while closing a children's reading tent in Uganda in Kajubu's (2005) article submits that school teachers/lecturers should help inculcate reading culture among their students because reading helps students to understand people's perspectives and it kills boredom therefore reading should not be left to students alone but parents and teachers should also be involved.

Based on the findings of this study, the following recommendations are hereby made: 
1. School/university and public libraries should be well organized and also provide adequate /reading materials

2. Government should try and reduce the cost of materials being used by publishing houses

3. The library, its environment and atmosphere should be friendly, conducive and comfortable for reading

4. In this world of digital age, libraries should provide computers (E-library or virtual library) to enhance reading

\section{References}

BBC Newsletter. Are Africans Reading Less? http/www.bbcnews.com Accessed on $20^{\text {th }}$ December, 2005

Commeyras, M. (2001) Promoting a reading culture. In for a vibrant reading

culture edited by Laolu Harolds. |The College of Education online news. The University of Georgia. Accessed on $20^{\text {th }}$ December, 2005

Holte, M. S. (1998) Creating an optimum reading culture in low countries: the role of Stichting Lezen. $\quad 64^{\text {th }}$ IFLA General Conference, Amsterdam. August 16-21

Ingham, B. (1993) The meaning of development: interactions between new and old ideas. World Development 21 (11), pp. 1803-1821

Jam, Z (1996) Promoting reading among children in Nigeria. African Journal of Library and Information Science 6 (2), pp 107-112

Kajubu, E. (2005) Develop a reading culture among pupils, envoy urges. The New Vision. Uganda's leading website. Http:/www/new vision online. Accessed on $20^{\text {th }}$ December, 2005

Kotei, S. I. A. (1978) Some cultural and social factors of book reading in Africa. In Publishing in Africa in the seventies; edited by Oluwasanmi, E. Ile Ife: University of Ife Press
Magara, E and Batambuze, C. (2005) Towards a reading culture for Uganda African Journal of Library, Archives and Information Science 15 (1), pp. 35-42

Makenzi, M. (2004) Reading out to the less advantaged: Reading tents in Kenya. World Library and Information Congress, $70^{\text {th }}$ IFLA General Conference and Council, $2227^{\text {th }}$ August, Buenos Aires, Argentina, pp. 1-10.

Nye, M. (2000) Culture and religion. Culture and religion: An Interdisciplinary Journal 1 (1), pp. 5-11

Ogunrombi and Adio (1995) Factors affecting the reading habits of secondary school students. Library Review 44 (4), pp. 50-57

Olubor , R. O. and Osunde, U.A. (2007) Analysis of personal study time and leisure among University undergraduates in Southern Nigeria. www.BNET.college student journal. Accessed on $17^{\text {th }}$ September, 2008

Onwubiko, M. C. A comparative study of reading interests of library educators and practicing librarians at the University of Ibadan. Unpublished MLS dissertation, University of Ibadan, Ibadan, 1985, pp. 6

Oyimnatumba, C. (2008) University of Ibadan celebrates $60 \mathrm{yrs}$.

Rijal, B. (2004) Can reading culture be a gift? Kantipur Online. www.kantipuronline.com Accessed on $20^{\text {th }}$ December, 2005

Rodney, W. (1972) How Europe Underdeveloped Africa. Tanzania Publishing House Limited. Pp, 226

Ugwoke, B. U. (2004) Developing youths potential through effective reading habits. The Nigerian library Link. A Journal of library and Information Science. 11 (1). Pp 40-45 